DOI: $10.1515 /$ pof-2016-0016

VOLUME 8, ISSUE 3, 2016

ISSN: $2036-5438$

\title{
Implication of Federalism in 'Federal' Related Political Institutions: A Conceptual Analysis
}

by

\author{
John O. Kalu and Dov Bing*
}

Perspectives on Federalism, Vol. 8, issue 3, 2016 


\begin{abstract}
While most students of federalism feel satisfied with defining it as involving self-rule and shared rule, there is an inherent laxity in that definition because several institutional forms have dual components of self-rule and shared rule. It is therefore necessary to find out if federalism is an equivalent of all self-rule - shared rule systems of government or not. This requires an effort to locate the implication of federalism in federal related political institutions, by exploring the conceptual distinctions between related terms such as federalism, federation, federal government, federal political systems, confederation, and decentralized union. Hence, this article aims at distinguishing these concepts, as well as identifying the interlinkage and relationship that exists between them. The goal is to reduce the level of uncertainty associated with the meaning of federalism in the contemporary political culture, and also, to make it less contested and distinct from other federal kindred terms.
\end{abstract}

Key-words

Federalism, concept, distinction, process, federal political institutions 


\section{Introduction}

Over the years, federalism has received substantial scholarly attention as governments tend to enlarge against the tides of regional fragmentations in modern societies. The concern has been on exploring and identifying what system of government would best address this problem of enlarging government and the counteracting pressure for autonomous local governance. The recurring themes of possibilities in the literature include concepts such as federalism, federation, confederation, decentralized unitary systems, and their hybrids. What these systems have in common is that each permits a combination of centralization and sort of decentralization of powers operating simultaneously; thus, they have been generally refered to as federal arrangements, federal political systems or federal institutional forms (Elazar 1987: 6; Watts 2008: 8; Stein 1968). Central to their discussions is the concept of federalism which appears, to some scholars, as the only system of governance that is poised to solve the problem in question.

However, analysis of relevant literature reveals a looming difficulty in differentiating federalism from each of the arrangements or systems mentioned above. Depending on what a particular writer aims at, federalism can be equated or associated with any of those institutional structures, and this has led some scholars to contemplate whether federalism is not meaningless. ${ }^{\mathrm{I}}$ More so, while the term 'federal political systems' has been proposed by Watts (2008) to represent a broad genus of political systems comprising confederations, federations, and decentralized unions, other writers restrict it to federations, federal states, and federal governments. With these contradictions, this paper arises to differentiate federalism and political institutional structures and also to establish the implication of the former in the latter, in order to reduce ambiguities that surrounds federalism and the federal concepts. As Elazar (1987: 14) argues, the choice of terminology strongly influences the direction and even the outcome of any inquiry. Therefore, distinguishing the federal kindred terms as clear as possible would help to reduce the level of uncertainty associated with the meaning of federalism in the contemporary political culture; making it less contested. 
This paper makes an extensive exploration of the concept of federalism from an historical perspective in order to understand its root and how this contributes to the ambiguities in the federal concepts. Specifically, in each section of the work we focus on a particular issue of controversy or a form of ambiguity with respect to the concepts. As we progress into latter sections, we analyse the similarities and differences that exist between the concepts and also attempt to distinguish each from another. The implication of federalism in each of the relevant institutional structures are discussed, aided with a table and some illustrative diagrams, in the last section before the conclusion. In the end, this study makes a significant contribution through simplifying what federalism is all about; as informed by historical and contemporary events in both the most notable and the debatable federal political societies. There is no doubt, this would eliminate perceived ambiguity, as well as make it less contested. Thus, it is expected that the article strengthens the taxonomies of the federal concepts, by re-examining the interconnections between the key political arrangements that are often included in the genus of federal political systems by scholars, and attempting to reconstruct them.

\section{Conceptualizing Federalism: Between a Process and an Institutional Structure of Government}

A question like 'what is federalism' attracts variety of opinions from different angles, as its process purports to achieve contradicting or opposing goals; including centralization and decentralization, unification and diversity, and combining self-rule and shared rule. Therefore, some scholars tend to associate federalism more with one aspect of the demands than the other; meanwhile, the pursuit of one aspect of the opposing goals over another differentiates the tenets of various institutional structures. For instance, scholars agree that federation is a system where there is equality between the desire for self-rule and shared rule, while confederation represents a system where the pursuit of self-rule trumps the desire for shared rule.

However, more problematic is the fact that earlier writers on the subject were not specific in the use of the term-federalism-to represent either the ideology that directs political actions towards achieving the specific goal, or the institutional structure established to attain it. For example, K.C Wheare focused on 'federal government' as the 
established system or institutional structure. Note his observation: most of those who use it [federal government] agree in this, that they have in mind an association of states, which has been formed for certain common purposes, [to be achieved through a central government], but in which the member states retain a large measure of their original independence, [through maintenance of their constituent governments] (Wheare 1963: 12). He went further to invoke the 'federal principle' as the idea that guides the relationships and interactions between central and constituent governments. This federal principle indoctrinates the method of dividing powers [in a federal constitution] so that the general and regional governments are each within a sphere co-ordinate and independent of one another (Wheare 1963: 10, 15).

To a large extent, Wheare's definition of the 'federal principle' conceptualizes what scholars came to understand and referred to as 'federalism'; even though he seldom used the term in the masterpiece-federal government. However, he saw this principle, first, as a core requirement only in a federation, federal government, or federal system; all of which he used synonymously. Secondly, he took this principle as an ideology that not only ends in guiding the design of a federal constitution, but also is reinforced in the day-to-day practice of the government. In his opinion, "if we are looking for an example of a federal government, it is not sufficient to look at the constitution alone, what matters just as much is the practice of government" (Wheare 1963: 20). To buttress, he adds that "the Nigerian constitution of 1960 purports to establish a federation and it clearly bears many characteristics of a federal system ... but it is too soon yet to judge whether, in practice, Nigeria will provide an example of a federal government or not". II

Subsequent scholars after Wheare began to analyse his work and reinterpreted, especially, his 'federal principle', as federalism; while using the terms - federal government, federal system, federal constitution, and federation synonymously as corollaries of federalism. To illustrate this, Livingston (1956: 1) in critiquing Wheare, noted that every discussion of federal government begins with the assumption that the problem concerned is one of legal formalism and formal jurisprudence, whereas ... legal answers are of values to legal problems, federalism is concerned with many other problems than those of legal nature. In addition, he added that federalism, like most institutional forms, is a solution of, or an attempt to solve a certain kind of problem of political organization. ${ }^{\text {III }}$ This inconsistent use of the terms is further evidenced in Riker (1964: 1) who posited that "well 
over half the landmass of the world was ruled by governments that with some justifications, however slight, described themselves as federalisms". One would think that Riker would mention federations instead of federalisms. Along the line, however, Riker wrote of unsuccessful federations and argued that "the moral of those failures is that federalism must be based upon some deeper emotions than mere geographic contiguity with cultural diversity" (Riker 1964: 33).

Carl Friedrich (1968) appeared to have noted the problem with the way federalism was confusedly being used to represent the process and also the structure of government with regard to division of powers, as he attempted to elaborate. He viewed federalism as an institutionalized process that has a constitutional protection as it is intended to reinforce the federal system. Hence, he argued that it is possible to define federalism and federal relation in dynamic terms. This leads him to conclude that federalism should not be seen only as a static pattern or design, characterized by a particular and precisely fixed division of powers between governmental levels (Friedrich 1968: 7). Federalism is also, and perhaps primarily, the process of federalizing a political community, that is to say, the process by which a number of separate political communities enter into arrangements for working out solutions, adopting joint policies, and making joint decisions on joint problems, and conversely, also, process by which a unitary political community becomes differentiated into a federally organized whole (ibid.). No doubt, Friedrich successfully exposed the problem but did little to resolve it, with his concession that federalism can be both a structure and a process at the same time.

Nevertheless, it was King (1982) that made the first bold attempt to confront the problem conceptually by analysing the terms in order to separate or distinguish federalism from federation. King relates the two terms analogously to a given political philosophy and the concrete plans set-up to achieve it. He views federalism as the political philosophy of diversity in unity, and federation as the established institutional structure to attain or promote this form of unity. ${ }^{\text {IV }}$ The connection between the two is not hard to establish and King points out that federation is governed by purpose; acting upon federalism and helping to shape and reshape both its expression and its goals (King 1982: 14). This position is adopted by Burgess (2006: 2) who takes federalism to mean the recommendation and (sometimes) the active promotion of support for federation - a particular kind of state and a distinctive organisational form or institutional fact. In his opinion, both federalism and 
federation have the main purpose of accommodating the constituent units of a union in the decision-making procedure of the central government by means of constitutional entrenchment; hence, federalism informs federation and vice versa.

Clearly, Elazar (1987) concurs to federalism being used in terms of a political philosophy to promote a particular type of unity among different political communities, but argues that federation is not the only institutional form that reinforces it. In his opinion, "using federal principle (or federalism) does not necessarily mean establishing a federal system or federation, in the conventional sense of a modern federal state" (Elazar 1987: 11). He argues further that "the essence of federalism is not to be found in a particular set of institutions but in the institutionalization of particular relationships among the participants in political life". $\mathrm{V}$ This assertion further compounds the problem beyond a 'process or ideology' (federalism) and an institutional form (federation, or federal state/government) by introducing the possibility of this same ideology being advanced through many other institutional forms.

\section{Federal Political Systems as Federations or inclusive of other arrangements?}

The notion that federal ideology can be pursued through several other arrangements other than federations raises a controversy over whether those other systems can be viewed as federal systems or not. In this vein, Watts (1998: 117) introduced the term 'federal political systems' to accommodate the other possible institutional forms, and further attempts to distinguish three terms: federalism, federal political systems and federation. He views federalism as a normative principle which aims at perpetuating both union and noncentralization at the same time; this is an endorsement of King's and Burgess' propositions. He posits federal political systems as a descriptive term referring to a broad genus of federal arrangements or political systems in which, by contrast to the single central source of political and legal authority in unitary systems, there are two (or more) levels of government combining elements of shared rule through a common government and regional self-rule for the governments of the constituent units. And he presents federation also as a descriptive term referring to particular species within that genus of federal political systems, which include other institutional forms such as unions, confederations, 
constitutionally decentralized unions, leagues, associated statehood, federacies, and condominiums (Watts 1998: 117; Watts 2008: 8).

Watts' description of federal political systems is particularly interesting as it shows that certain similarities do exist in various institutional forms which, to a large extent, aim at reinforcing diversities in unity just as federations. However, christening this broad genus of political organizations as federal political systems complicates rather than simplifying the problem it purports to ease. It makes it difficult to define what a federal government or federal state should mean-whether it should be used when referring to a federation or any other species within the broad genus. As Burgess (2013: 51) rightly puts it, the notion of federal political systems, in the context which Watts postulated it, is a deceptively complex term which lacks conceptual precision. Furthermore, this distinction tends to subordinate federation to a mere species of a genus that remains somewhat ambiguous, whereas, federation (as a federal state) is something that, by virtue of its very statehood, sits uncomfortably in the mixed company of those other forms in the broad genus (Burgess 2006: 48).

Stein (1968) provides a contrasting view of a federal political system, which tends to support its restriction to federations just like Burgess argues above. In his view, “a federal political system is that form of political system (of a nation-state) in which the institutions, values, attitudes, and patterns of political action operate to give autonomous expression both to the national political system and political culture and to regional political subsystems and subcultures (defined primarily by ethnic-linguistic factors)" (Stein 1968: 731). He added that the autonomy of each of these systems and subsystems is counterbalanced by a mutual interdependence, such that the balance maintains the overall union. The enunciated features represent those of a federation and not of the several other species. No wonder Burgess (2013: 54) vehemently posits that "just like every state has a political system ... we would expect to find a federal political system in a federal state, federal government, or federation'-all of which are synonyms.

Notwithstanding, what is clear from the foregoing, however, is that there is a strong reason that has prompted Watts to cast the net of federal political systems so wide to capture other species of political arrangements, in addition to federations that supposedly are the natural embodiments. It would be totally unfair to disregard the merit in his classifications; instead, investigating the interconnections between the key political 
arrangements he included in the genus of federal political systems will be instructive. This task is tackled below.

\section{The 'Foedus' Connection}

Against the controversies over federalism and the federal arrangements, the interconnection is found in the consensus that the root word 'federal' stems from the Latin word foedus, which means 'treaty', 'compact' or 'contract' of alliance between political entities. Many students of federalism have written consistently about how 'foedus' was used when referring to treaties between independent entities, united by a sense of common needs like war, especially in the medieval Roman Empire. ${ }^{\mathrm{VI}}$ Elazar (1987) veers deeper into the etymology of federalism beyond the Latin foedus by tracing further the root of foedus to the Hebrew term 'b'rit', which means covenant. He therefore posited that, "federal arrangement is one of partnership, established and regulated by covenant, whose internal relationships reflect the special kind of sharing that must prevail among the partners, based on mutual recognition of the integrity of each partner and the attempt to foster a special unity among them" Elazar (1987: 5).

Due to the connection of federalism to the Hebrew b'rit and Latin foedus, many scholars believe that the practice of federalism predates civilization; existing from about 1000 B.C.E, in the ancient Israel and Greece, to the medieval period that saw the rise of the modern nation-states. ${ }^{\text {VII }}$ This would be fallacious to many others who believe that federalism is, concretely, 'American invention'. ${ }^{\text {VIII }}$ Whichever camp a scholar inclines to regarding the origin of federalism influences what the scholar views federalism to mean. Meanwhile, implicit concessions can be deduced from each of the camps. For instance, the first argues federalism had been prior to the American alleged invention; yet, do observe a great difference that might be called a departure from the earlier models, in the form that the American founding fathers introduced. ${ }^{\mathrm{IX}}$ In that vein, Elazar and some others in that category would refer to the American style as the 'modern federalism'. The second group on the other hand, concedes that something similar to the American style had existed in the pre-American societies. ${ }^{\mathrm{X}}$

These two ways of viewing federalism-pre-modern and modern-created the foundation for ambiguity over the subject, as the structure identified in each instance is 
equated with federalism. The result is the conclusion by some scholars that there are different shades, representing different structures, of what qualifies as federalism (Livingston 1956: 4; Riker 1964: 6; Elazar 1987: 6; Watts 2008: 8-9). Of course, hardly would a particular society escape from being classified as modelled along the so-called 'premodern' medieval European federalism or 'modern' American styled federalism. The variation in the structure each society presents, even though modelled along a particular tradition, further creates another shade. Nevertheless, the debates in relation to the design of the American Constitution by the founding fathers provide sufficient insights to the understanding of federalism in the two traditions, and the issues that confound contemporary federal institutional structures.

\section{Issues in differentiating 'Federal' related Institutional Forms}

The American founding fathers are largely credited as the inventors of 'federalism' by drafting the US Constitution, which established a novel system of government that has come to be regarded as the premier 'federal government', 'federation', or 'federal state'. This design resulted as a by-product of their pursuit to consolidate independence from their imperial master-the British. While federalism or 'foedus' based system of political organization was a consensus choice, pursuant to creating an egalitarian society, fighting the war of independence however exposed to them the weaknesses inherent in the kind of foedus associations they had known-the supposed medieval federal models. This led to the emergence of opposing views of federalism, supported by different kinds of federalists during the debates at the Philadelphia Constitutional Convention of 1787. At one time, the debates linked federalism to centralization and at another time, they referred it to strong constituent units. ${ }^{\mathrm{XI}}$ This ambiguity was a source of confusion, affecting how the future American leaders were going to operate the governing tool they had been bequeathed. Other emerging federations that adopted the American style equally inherited similar problematic.

Against the ambiguity around understanding the kind of federalism established in the American Constitution, Diamond (1963) offers a valuable suggestion towards resolving this. In his opinion, objective bases to understanding the framers are perceptible through a number of events and documents which includes: the Declaration of Independence; the 
Article of Confederation; the proceedings of the federal convention; the Constitution's ratification - the various federalist essays (Diamond 1963: 24). He explains further that the Declaration document is the primeval statement of the American political principles; the Article of Confederation was the constitution that was rejected; the proceedings are the extraordinary record of the way the constitution came about; the federalist essays are the brilliant and authoritative exposition of the meaning and intention of the constitution; and the arguable anti-federalist essays are the thoughtful defence of the political tradition the constitution was displacing. However, if one follows Diamond's suggestions, to examine the mentioned documents and incidents, ambiguity in the manner the founding fathers used the term 'federal' still persists.

\section{Confederation or Federation?}

As noted by several scholars, the authors of 'the federalist' applied the term 'federal' (foederal) to both the government under the Articles of Confederation and the one proposed in the new Constitution (Wheare 1963: 10-11; Forsyth 1981: 107; Friedrich 1968: 18-20; Ostrom 1991: 70). The terms 'confederation' and 'federal' were used essentially as synonyms and for different referents; any difference in meaning to be ascribed to the new concept depended upon context. ${ }^{\mathrm{XII}}$ However, what was obvious is that the two terms were used interchangeably as opposite to a national or unitary government, which was seen as one extreme of political organization, where only one single political entity exists and, thus, power is concentrated in one general government.

Confederation, from earlier systems that were properly named so including the Swiss confoederatio (1291) and the US Articles of Confederation (1781-1789), basically means there are two or more associated entities which bind themselves in 'foedus' or treaty to 'federalize' by forming a common government for certain purposes. It can be called a treaty government. As such, the defining characteristic of a confederacy is that the associated states retain all the sovereign power, with the central body entirely dependent legally upon their will (Diamond 1963: 26). However, a close scrutiny of the new system established in the US constitution reveals a marked departure from that characteristic. For example, in reference to this new system, Alexis de Tocqueville posited that "this is no longer a 'federal' government, but an incomplete national government, which is neither 
exactly national nor exactly 'federal', but the new word which ought to express this novel thing does not yet exist" (Cited in Bradley 1945: 159). Observe that 'federal' in this assertion refers to confederation, which was the only known alternative form of government to counteract imperial powers as at then. It is undoubtedly confusing but the analysis below illuminates the ensuing distinctions.

\section{National/Unitary Government, Confederation, and Federation/Federal Government}

It is clear that the US constitution framers were battling between two extremes of political organization, which were national/unitary government and confederation. The former represents the kind of centralized federal government proposed by Alexander Hamilton, while the latter represents the kind of decentralized federal governance desired by those that opposed Hamilton's view. This second group was eventually labelled 'antifederalist' as Hamilton had been parading his views as the 'federalist'. In the end the delegates rejected the extreme degree to which Hamilton's initial plan concentrated power at the national level, but they understood that giving more power to the central government was necessary for the nation's survival—a point Hamilton had succeeded to establish. Therefore, the emerging constitution was a compromise of the two opposing views of federalism at the convention. The federalist decisive statement confirms this: "the proposed constitution, therefore, is, in strictness, neither a national nor a federal ${ }^{\mathrm{XIII}}$ constitution, but a composition of both" (Diamond 1963: 26).

In the contemporary, the term 'federal' is ascribed to the new system, which the framers regarded as possessing both federal (hitherto, confederal) and national featuresthe same system that Tocqueville had noted as requiring a new name to differentiate. This leaves 'confederation' to stand entirely as the opposite of 'national' (unitary state) while the new 'federal' becomes the middle system which modifies the two by combining their best characteristics (Diamond 1963: 26). Therefore, as the opposite of a confederation, a unitary state or national government is a political organization where the society is treated as one single political entity; thus, power is concentrated in one level of government. Instrumentalities are not created to recognize the differences between distinct groups or to address their yearnings in the polity. It can be seen as a system where groups come to bind 
themselves in 'foedus' by establishing a general government that is empowered to possess every power hitherto held by each group. Hence, the defining characteristic of a unitary system is that the constituent units are entirely dependent on the will of the general government, which retains all the sovereign power. In the event that political communities within the unitary state start to agitate and a minimal level of instrumentalities are created to cater for the needs of these different entities, another shade of federal arrangement emerges in the form of a 'decentralized union'.

\section{Federalism as a Complement of Federation}

Diamond's exposition, ${ }^{\text {XIV }}$ when he observed that the emergence of the United States Constitution was as a result of the need to change the principles in the Articles of Confederation which allowed for subordination of the central government by the sovereign constituent states, reinforces Wheare's conceptualization; thus: "it justifies us in describing the new principle, which distinguishes the US constitution so markedly and so significantly, as the "federal' principle" (Wheare 1963: 10). Wheare seemed very correct in the sense that the embattled constitution supposedly had 'confederation principles' as suggested by its name-Articles of Confederation. Hence, the new one, having been presented as not being a 'national/unitary' constitution, and, also, not being the same as the replaced 'confederation' constitution, could only logically be described as a 'federal' constitution. This was how Wheare concluded that the federal principle should be the yardstick to distinguish a federal system; meaning that neither level of government would entirely depend upon the will of the other as in a confederation or national union.

Resulting from the above, it could be argued that federalism is not a sine qua non for any other system of government other than a federation. This seems to be a well-known fact as the writings of many scholars indicate. Particularly, Riker (1964: xii) makes it clear that he set out to develop the study of federalism with the aim of generating hypotheses that could be tested in the US system, from which the artefacts of federalism has been derived, and other federations. He did not hope to test federalism in any other system within the socalled broad genus of federal political institutions. The attempt to link federalism to those other systems as proposed by Watts requires further qualifications; because federalism outside a federation may happen as a departure from the tenets of the particular system in 
question towards metamorphosing into a federation. As King (1982: 76) argues, there may be federalism without federation, as can be seen in some other systems of government; however, this is not intended at the outset but only results because the system in question is decentralizing and moving towards a federal republic. Therefore, the argument would be that, those other transitional systems where federalism is perceived should be viewed as different kinds of federation, and not totally in terms of their original forms as separate species such as confederation, or decentralized unitary among others. But, regardless of how they are being looked at, the reality is that federalism is evident in those societies and may just be a matter of time before they upgrade to a full federation; as is currently the situation with the European Union.

\section{Discussion: Implication of Federalism in 'Federal' Political Institutions}

A re-consideration of the conceptual debates shows that federalism has rarely been defined concisely without describing its essence. Meanwhile, when a description is employed, what is presented is the picture of a federation, which explains why there has been an interchanging use of federalism and federation by some writers. ${ }^{\mathrm{XV}}$ While attempts have been made to separate or at least distinguish the two, especially in the mainstream Anglo-American literature, it does not appear to raise any concern in the European literature; i.e. the French school of integral federalism and their Italian counterpart. Influenced by the philosophies of Immanuel Kant (1724-1804), Pierre-Joseph Proudhon (1809-1865), and, to a lesser extent, Carlo Cattaneo (1801-1869), scholars in this tradition view federalism as an ideology, which goes through a given process in order to attain its targeted values. ${ }^{\mathrm{XV}}$ Rather than stressing the institutional aspect through which the 'federalism-federation' controversy would arise, they pay more attention to determining what characterizes a federal society, what the core values of federalism are, and the various levels of political organization where federalism is plausible.

We take a particular note of Albertini's assertion that federalism cannot be limited to the conception of a type of a state, because this would constitute only a small part of its general meaning (2000 [1963]: 88). Concretely, he argues that limiting federalism to a federal state takes no account of the fact that a state always rests on a social base which 
conditions its existence, and the nature and working of its institutions are determined by particular types of political behaviour (Albertini 2000 [1963]: 88). Meanwhile, Proudhon relied on Althusius' emphasis on contract to identify federalism from the level of coming together of heads of families, the communes, the cantons, the provinces, and to the state, in order to guarantee a harmonious living together and reduce the prospect of clashes in the society (Friedrich 1968: 26). Kant on his own part had the idea of a worldwide federation of republics as a prerequisite to forestall inter-state conflict (Friedrich 1968: 24). But one common denominator in the thoughts is that, in each instance and level, federalism consisted of a continuous interaction between a certain kind of an inclusive community and component communities.

Undeniably, there is usually the possibility for the individual interests of the component communities to clash against each other and that of the inclusive community; nevertheless, that is what federalism lives to regulate. Therefore, it is not surprising that the pursuit for 'peace' has been identified as the core value of federalism; a finding that has deservedly gained wide acceptance especially among the European federalist scholars (See: Albertini 2000 [1963]: 90; Castaldi 2007: 3; De Rougemont 1947: 25; Dosenrode 2010: 10-11; Levi 2008: 53; Marc 1961; Rossolillo 1989: 31). But, would it be possible to focus on a value of an ideology in the absence of an institution through which the value could be realized? As rightly observed by Albertini (2000: 89) conceptualizing federalism from an ideological point of view alone is not in touch with reality, as it cannot identify precise forms of behaviour or definite realities. He further suggested that alongside the ideological perspective, federalism should also be approached from the institutional lens, as it definitely has a structural aspect (the federal institution), a socio-historical aspect (the complex historical and social conditions that divide a society into groups, classes, and nations), and a value aspect (attainment of peace by overcoming or managing those sociohistorical divisions in a society) (Albertini 2000 [1963]: 90-110; see also, Castaldi 2007: 3).

From Albertini's tripartite aspect of federalism, we see the socio-historical aspect as the nucleus of what conditions the emergence of a federal process/behaviour. When we understand the place of socio-historical factor, then it will even be easier to recognize the institutional structure that can foster realization of the core value of federalism-peace. To explain in simple terms, socio-historical basis refers to the primordial loyalty of a people, their psychology and overall disposition towards others in a society, arising from prior 
separate settlements in distant territories which made it difficult to be in regular contact with, if ever aware of the existence of, the others until a particular event happened which began to bring them together. Such event could relate to war, as in the case of the United States of America, or colonialism, as in the case of Nigeria. In any case, the hitherto separate groups have been made to come together (socio-historical aspect), and a common union is formed (institutional structural aspect), with a task to secure the peace of all, without attempting to subjugate each other, which brews conflict (value aspect); even though that is not always an easy task.

Now, how does the above exploration contribute towards determining the implication of federalism in various [federal] political institutions? The answer is simple; having established federalism as an ideology that has a structure, and a specific value towards overcoming or managing socio-historical based bipolarization, it is therefore logical to see federalism as the operational attempts to safeguard balance and equilibrium (i.e., as proposed in Wheare's federal principle) between a central and regional governments as aimed at in a federation (Kalu 2016: 353). It should be noted that other [federal] institutional forms might reflect certain glimpses of the federal principle, like each level of government having some areas of independent spheres. But certainly, they do not aim at ensuring equilibrium between the levels of government, as their structure is designed such that one level (either the central government, or regional government) predominates the other in a given instance. Hence, any practice or process of governance that does not strictly aim at reinforcing equilibrium, or non-subordination, of levels of government in a federation or within any other [federal] institutional form, can hardly realize the core value of federalism. Such could be viewed as 'not federalism' or dis-federalism ${ }^{X V I I}$ instead.

With this understanding, one may argue that among all the arrangements regarded as federal institutional forms (including: federation, confederation, and decentralized union), federalism, in its truest sense, is a prerequisite only in a federation, where there is a need to achieve a balance between unity and diversity; not in any other one. The inter-relationship is further explained: firstly, federalism, when viewed as a process of federalizing, aims at ultimately setting up a federation; and in practice, federalism also reinforces a federation after it is set up. Secondly, while federation sets the rules for federalism, it is the federal operation that safeguards the structure of the federation. This is fully illustrated in table 1 below. 
Table 1. Inter-relationship between federalism \& Institutional forms

\begin{tabular}{|l|l|l|}
\hline $\begin{array}{l}\text { INSTITUTIONAL SET- } \\
\text { UP AT THE OUTSET }\end{array}$ & $\begin{array}{l}\text { PROCESS OF } \\
\text { GOVERNANCE }\end{array}$ & $\begin{array}{l}\text { RESULTANT } \\
\text { STRUCTURE OVER A } \\
\text { PERIOD OF TIME }\end{array}$ \\
\hline FEDERATION & Federalism & FEDERATION \\
\hline CONFEDERATION & Federalism & FEDERATION \\
\hline UNION & Federalism & $\begin{array}{l}\text { FECENTRALIZED UNION } \\
\text { OR CONFEDERATION }\end{array}$ \\
\hline FEDERATION & Dis-federalism & CONFEDERATION \\
\hline CONFEDERATION & Dis-federalism & DECENTRALIZED UNION \\
\hline DECENTRALIZED & Dis-federalism & \\
\hline
\end{tabular}

Table 1 above shows how federalism relates with the major 'foedus' inspired institutional forms; i.e., institutions marked by the presence of two levels of government that have varying degrees of autonomy in relation with each other. These include federation, confederation, and decentralized union. From the table, it can be seen that apart from a federation, no other form of government should aim at practicing federalism if it desires to remain intact and unadulterated, otherwise, a consistent practice of federalism would change any institutional form to a federation over a period of time. ${ }^{\text {XVII }}$ Similarly, federations should adhere strictly to the practice of federalism, otherwise, it will seize to being a federation and might evolve into a confederation or decentralized union; depending on which level of government becomes more powerful against the prior equality. The information presented in the table can be re-interpreted with basic circles to show the process that describes federalism, as well as distinguishes it from federation; while also demonstrating the relationship between federalism and the various institutional forms as shown in Figure 1 below. 
Figure 1. Federalism process - without distortion

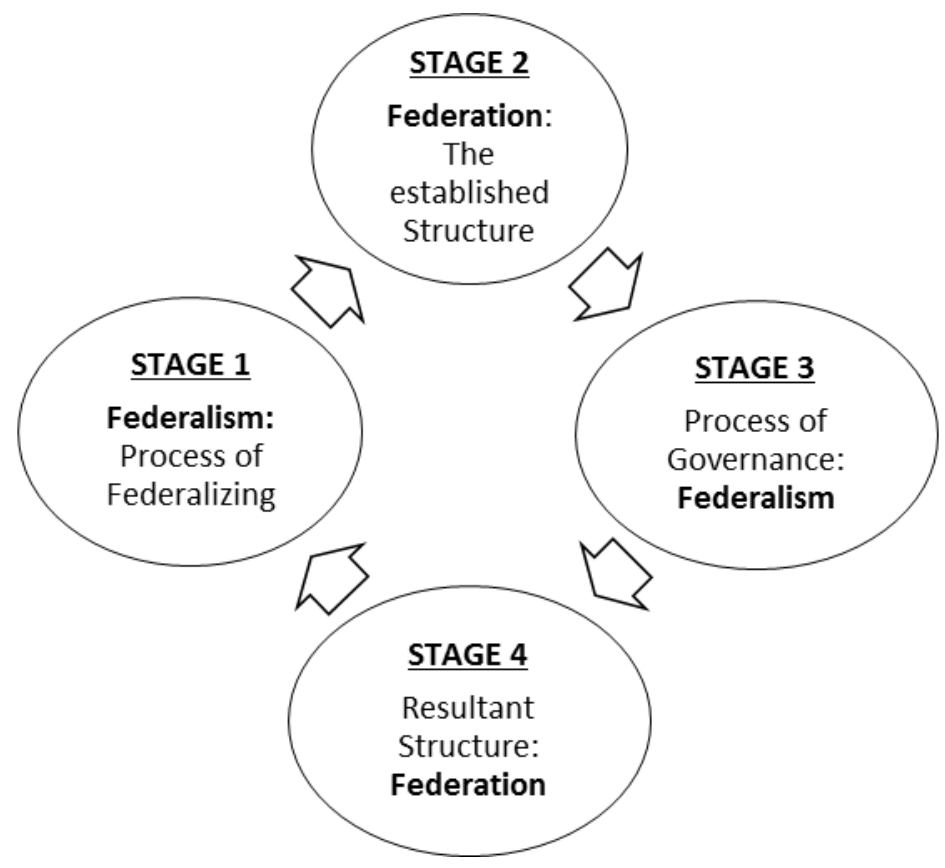

From Figure 1, we see federalism, first and foremost, as a process of federalizing by which a number of separate political communities enter into arrangements for working out solutions, adopting joint policies, and making joint decisions on joint problems (see stage 1). Then, the structural arrangement that is set-up to bring about the desired solutions to their joint problems is a federation as depicted in stage 2. Furthermore, we see federalism as the process of governance in the federation to maintain the designed structure as pointed on stage 3. Lastly, we see federation remaining intact as the structure of government for the society in stage 4 . The whole process illustrates the process of federalism in relation to the governance in a federation as the complementary institutional structure.

Nonetheless, if after setting up a federation through federalizing process (see stages 1 $\& 2$ ), and the operation or process of governance (see stage 3) undermines adherence to the federal principle or federalism, then, the resultant structure over a period of time cannot reflect a federation anymore, as stage 4 in Figure 2 below shows. Depending on which level of government that becomes more powerful, the resultant structure could change to confederation or decentralized unitary. Should there be further need to correct the structure to federation, the constituent units have to federalize again, through 
constitutional making in order to restructure, and the process continues. This is illustrated in Figure 2.

Figure 2. Federalism process - when distorted

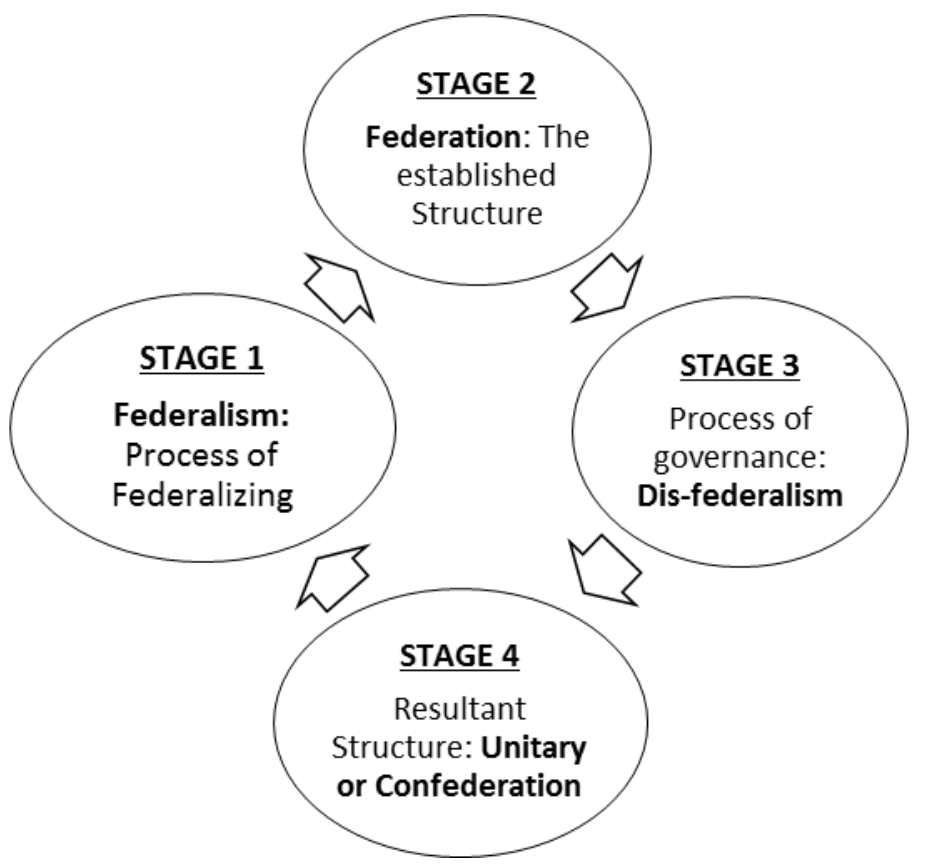

\section{Conclusion}

Locating the implication of federalism in federal related political institutions, as this article focuses on, has exposed the need for conceptual distinction of the related concepts. In this course, it has been found that federalism has confusedly been viewed as a structure, or a process, and/or, as both. In addition, confederation, federation, and decentralized union are related structures that have been found to be associated with federalism in one way or the other. Furthermore, federal system and federal government are terms that represent a specific system of government where federalism is practiced. The main challenge of this article has been to distinguish these concepts as clear as possible, and also to identify the interlinkage and relationship that exists between them. This is to ensure that we contribute to reducing the level of uncertainty associated with the meaning of federalism in the contemporary political culture, and also, to make it less contested and distinct from other federal kindred terms. Therefore, after the entire analysis in this work, the following conclusions are drawn with regard to the concepts: 


\section{a) Federalism}

Federalism is the practice or style of governance (an institutionalized process) that aims towards the unification of entities and the reinforcement of a corresponding level of independence among territorial entities in a given political space. Let us understand that this task is not always that simple to achieve, as the pull for unification is constantly in opposition to the desire for independence and vice versa, but once the aim remains constant, then a level of federalism is in process. Consequently, the degree of conquest of unification over independence, or the other way round, results in a variety of federal institutional forms. However, when this goal for unification and maintenance of independence is constitutionally entrenched, as in a federation, and strictly adhered to by the various governments in practice, without the attempt by any to suppress each of the demands, then federalism would have achieved its ultimate value of equalizing unity and diversity — the attainment of peace.

\section{b) Federation}

A federation is a conscious legal institutional structure which comprises a territorial division of government into two levels - the central and constituent governments-which firstly, is purposed to reinforce the quest for union and desire for diversity; secondly, where each government is independent in its own sphere as established in the constitution and also cooperates in the general sphere; thirdly, where none is superior or subordinate to the other; and finally, where no government can overrun or pull out of the partnership, unless mutually agreed. It is important to re-emphasize that federation is synonymous with federal government and federal state.

\section{c) Federal System or Federal Political System}

A federal system refers to a political system that is, first and foremost, structured as a federation, and then relies on federalism as the means for its governance. ${ }^{\mathrm{XIX}}$ While there are scholars who want the term 'federal political system' to apply to any system where there are two or more levels of government within a society including a decentralizing unitary state and a centralizing confederation, many problems result with such a broad classification. First, it leads to a confusion as a country should not be classified, for instance, as a federal political system, while at the same time operating a unitary constitution. Secondly, most of those systems included in that classification do not portray any significant systemic expression of the federal principle, as subordination of each level by another is 
overwhelmingly evident. Thirdly, a system should include basic structure, the entire linkages of activities, operations and interactions within the political system to qualify as a system. Hence, a federal political system should be restricted to a federation, which operates a federal constitution and also remains reliant on federalism as the means of governance. Other terms for this includes federal government or federal state.

\section{d) Federal Institutional Forms}

Federal institutional forms include all institutional arrangements where there are two or more levels of government in a society, each having a separate areas of autonomous activity, regardless of whether this independent jurisdiction is constitutionally entrenched or it can be dissolved and quashed at the will of the central government. They include 'federation', 'confederation', and 'decentralized union'.

One may question why apply the adjective 'federal' to institutions that historical experience and contemporary knowledge has thought us to distinguish as confederal and/or decentralized union, instead of leaving 'federal' institutional form to federations only. While it potentially appears valid, a number of factors make it difficult to exclude those other structures as forms of 'federal' institutional structures. For instance, it is a wellknown fact that the term 'federal' originates from the Latin word 'foedus' (meaning: covenant). Therefore, any arrangement that is based on 'foedus' or its derivative 'covenant' should logically qualify as a form of federal arrangement. The reason is that, at the foundation of each remains the commitment to the 'foedus' principle of safeguarding a level of self-rule for each of the territorial groups and a shared-rule for all. In addition, there is usually some kinds of treaty documents that warrant the protection of each group's distinct identities, regardless of how much valuable the quest for unification becomes. Even so, to qualify as a federal system/federal state the nature of the covenantal relationship, as seen from the constitution of the system in question and its practice, has to be such that the levels of government operate as partners and not as master-servant. ${ }^{\mathrm{xx}}$

To conclude, in terms of the implication of federalism in each of the federal institutional forms, it can be deduced that federalism, in its truest sense, is a prerequisite for, and in, a federation alone, where there is a need to achieve a balance between unity and diversity; not in any other institutional form. Nevertheless, there is a caveat. It is possible (and even highly evident) to see federalism developing in each of the other institutional forms, where there are provisions to recognize, protect and nurture the diversity of the 
people, ${ }^{\mathrm{XX}}$ or consolidate an emerging inclusive union, ${ }^{\mathrm{XXI}}$ by means of government legislations. But the reality is that, if federalism persists overtime, then the structure of that institutional form is bound to change to a federation, when the constituent units and central government become equal partners with full constitutional security, regardless of whether it was a confederation or decentralized unitary state in the past. Similarly, a federation should adhere strictly to the practice of federalism by consolidating equilibrium between subject's two poles of loyalty, otherwise, it will seize to being a federation and might evolve into a confederation or decentralized union; depending on which level of government has become more powerful against the prior equality.

\footnotetext{
* John O. Kalu got a PhD in Political Science and Public Policy from the University of Waikato, New Zealand. He is currently a postdoctoral researcher at the Department of Political Science and Public Policy, University of Waikato. Professor Dov Bing is the graduate students' advisor at the Department of Political Science and Public Policy, University of Waikato.

I See, for instance, Wright 1978; Walker 1981; Davis 1978.

II See, particularly, Wheare 1963: 29).

III Firstly, it can be seen that Livingston has in this instance replaced the federal principle, which Wheare mostly used, with federalism; Secondly, he also referred federalism as an institutional form.

IV See King 1982: 21.

V Elazar 1987: 12

VI They include: Elazar 1987: xii; Friedrich 1968: 18; Riker 1964: 8; Davis 1978: 18; Lépine 2012: 29.

VII For further observation in addition to citations in note VI above, see Riley 1973: 52; Lépine 2012: 30.

VIII For example: Wheare 1963: 1; Friedrich 1968: 11; Hueglin 1990: 4; Wright 1961: 41; Føllesdal 2014; Hueglin and Fenna 2006.

IX This concession can be seen in the following, Elazar 1994: 123; Riker 1964: 10; Riley 1973: 51; Lépine 2012: 29; Davis 1978: 119.

x Clear evidence can be found in Hueglin 1979: 40; Wright 1961: 42; Friedrich 1968: 18; Wheare 1963: 1.

xi See Diamond 1963: 24-26; Ostrom 1991: 70; Forsyth 1981: 107; Wheare 1963: 11; Friedrich 1968: 18-20.

XII Wheare 1963: 10; Ostrom 1991: 70.

XIII See, Federalist Paper, No. 39; As a matter of fact, 'federal' mentioned here would have been 'confederacy', if the distinction had been employed.

XIV Diamond 1963: 29-32.

xv See, Watts 2008: 8; King 1982; Burgess 2013; Ostrom 1991: 85; Wheare 1963; Riker 1964; Elazar 1987.

XVI See: Spinelli 1967; Albertini 2000 [1963]; Rossolillo 1989; Levi 2008; Marc 1961; De Rougemont 1947; Dosenrode 2010.

XVII The prefix 'dis-', has been introduced by the author because it stands for 'opposite' or a misapplication of something, which perfectly fits the argument advanced here.

XVIII This is well supported even by the European federalist scholars, including Albertini 2000: $97-107$ and Dosenrode 2010: 11, both of who confirm that federalism is a process leading or attempting to lead to a state of federation.

XIX See Elazar 1987: 5-6; Wheare 1963: 29.

$\mathrm{xx}$ The citations in note XVIII above provide justification for this conclusion; see also: De Rougemont 1947: 25.

XXI The structure of governance in the United Kingdom, the European Union, Spain, Italy, Finland, and to a lesser extent, New Zealand, are all testimonials.

XXII While in most cases the federal problem is about how to adequately empower the constituent units, the case of the European Union however clearly represents the problem of consolidating an emerging new union against the preponderance of its constituent units.
} 


\section{References}

- Albertini Mario, 2000 [1963], 'Federalism', in Rossolillo,Francesco (ed), The Federalist: A Political Review, XLII(2): 87-112.

- $\quad$ Bradley Phillips (ed), 1945, Democracy in America by Alexis de Tocqueville, Vintage Books, New York.

- $\quad$ Burgess Michael, 2006, Comparative federalism: Theory and practice, Routledge, New York.

- Burgess Michael, 2013, 'The penumbra of federalism: A conceptual reappraisal of federalism, federation, confederation and federal political systems', in Loughlin John, Kincaid John \& Swender Wilfried (eds), Routledge Handbook of Regionalism and Federalism, Routledge, New York.

- Castaldi Roberto, 2007, A federalist framework theory of European integration, Centro Studi di Federalismo, Moncalieri.

- Davis Solomon Rufus, 1978, The federal principle: A journey through time in quest of a meaning, University of California Press, Berkeley, CA.

- De Rougemont Denis, 1947, 'The Federalist Attitude' in Lipgens Walter and Loth Wilfried (eds), Documents on the History of European Integration.

- Diamond Martin, 1963, 'What the framers meant by federalism', Goldwin Ronald A. (ed), A nation of states, Rand McNally, Chicago.

- Dosenrode Søren, 2010, 'Federalism theory and neo-functionalism: Elements for an analytical framework', Perspectives on Federalism, II: 1-28.

- $\quad$ Elazar Daniel Judah, 1987, Exploring federalism, University of Alabama Press, Tuscaloosa, AL.

- Elazar Daniel Judah, 1994, 'Federalism and the way to peace', in Relations, Institute of Intergovernmental (ed), Reflections Paper, Queen's University, Kingston, Ont.

- Føllesdal Andreas, 2014, 'Federalism', in Zalta Edward N. (ed), Stanford Encyclopedia of Philosophy, Spring, 2014 ed. online (http:// plato.stanford.edu/archives/sum2016/ entries/federalism).

- Forsyth Murray, 1981, Unions of states: The theory and practice of confederation, Leicester University Press, New York.

- $\quad$ Friedrich Carl J., 1968, Trends of federalism in theory and practice, Pall Mall Press, London.

- Hueglin Thomas, 1979, 'Johannes Althusius: Medieval constitutionalist or modern federalist?', Publius, IX: 9-41.

- Hueglin Thomas, 1990, A political economy of federalism: In search of a new comparative perspective with critical intent throughout, IIGR, Queen's University, Kingston, Ont.

- Hueglin Thomas O. \& Fenna Alan, 2006, Comparative federalism: A systematic inquiry, University of Toronto Press, Toronto.

- Kalu John Otisi, 2016, 'True Federalism? Illustrations With The Venn Diagram', European Scientific Journal, XII: 344-365.

- $\quad$ King Preston, 1982, Federalism and federation, Croom Helm, London.

- Lépine Frédéric, 2012, 'A journey through the history of federalism: Is multilevel governance a form of federalism?', L'Europe en formation, no 363 Printemps: 21-62.

- $\quad$ Levi Lucio, 2008, Federalist thinking, University Press of Amer., Lanham, MD.

- Livingston William S., 1956, Federalism and constitutional change, Oxford University Press, London.

- Marc Alexandre, 1961, Dialectique du déchaînement: fondements philosophiques du fédéralisme, La Colombe, Paris.

- Ostrom Vincent, 1991, The meaning of American federalism: Constituting a self-governing society, ICS, San Francisco, CA.

- $\quad$ Riker William H., 1964, Federalism: Origin, operation, significance, Little Brown, Boston, MA.

- $\quad$ Riley Patrick, 1973, 'The origins of federal theory in international relations ideas', Polity, VI: 87-121.

- Rossolillo Francesco, 1989, 'Federalism and the Great Ideologies', The Federalist: A Political Review, XXXI(1): 7-34.

- $\quad$ Spinelli Altiero, 1967, 'European Union in the Resistance', Government and Opposition, II: 321-329. 
- $\quad$ Stein Michael B., 1968, 'Federal political systems and federal societies', World Politics XX: 721-747.

- Walker David Bradstreet, 1981, Toward a functioning federalism, Winthrop Publishers, Cambridge, MA.

- Watts Ronald L., 1998, 'Federalism, federal political systems, and federations', Annual Review of Political Science, I: 117-137.

- Watts Ronald L., 2008, Comparing federal systems, McGill-Queen's University Press, Kingston, Ont.

- Wheare Kenneth C., 1963, Federal government, Oxford University Press, London.

- Wright Benjamin Fletcher (ed), 1961, The Federalist by A. Hamilton, James Madison, and John Jay, Belknap Press of Harvard University Press, Cambridge, MA.

- Wright Deil Spencer, 1978, Understanding intergovernmental relations, Brooks-Cole, Pacific Grove, CA. 